\title{
AN OVERVIEW TO IRANIAN JUDICIARY BUDGET IN IRAN'S CONSTITUTION
}

\author{
Issa Daneshpour Bakhshayesh* \& Nina H. A. Mohammady ${ }^{* *}$
}

Budget is one of the mutual cooperation and balancing spheres between tripartite powers, which all of the annual incomes and costs are counting in this deed. According to Iranian constitution, the executive power is responsible to prepare this deed, and the exclusive sector (Nahad) for ratification is legislative power. However, so-called two powers are monitoring the usage (Ejra) of the budget, judiciary power's role only limits to usage of its own budget. Whereas, giving (E'ta) wide amount of authority to executive and legislative powers in this case is in contrast with principles 57 \& 156 of Iranian constitution (which emphasizes on independence of judiciary power), this process leads to commercial dependence of judiciary power. ${ }^{1}$

INTRODUCTION 307

I. Evaluation Judiciary's Power in Budgeting Process ....................308

A. Preparing and Proposing the Budget .......................................308

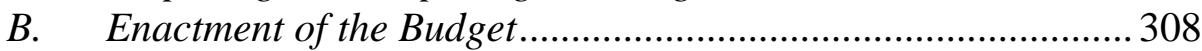

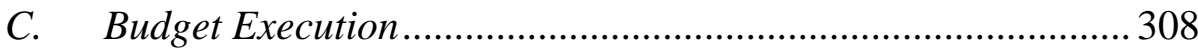

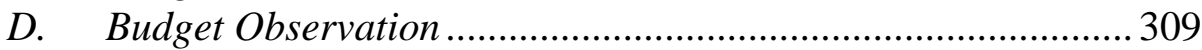

II. NECESSITIES Of JUdICIARY BuDGET's INDEPENDENCE .........................309

A. Separation of Power .......................................................... 309

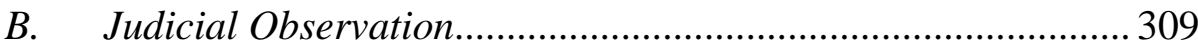

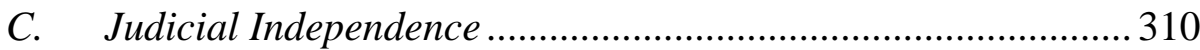

D. Wide Sphere of Authorities ................................................ 310

III. UNIFICATION OF BUDGET, IN CONTRAST WITH BUDGET INDEPENDENCE

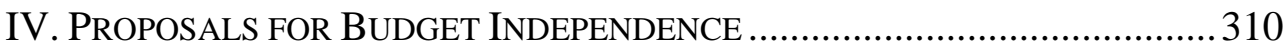

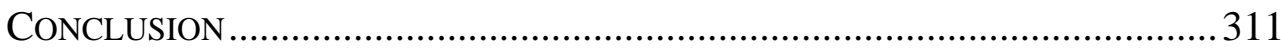

\section{INTRODUCTION}

According to Iranian Budget Law, all the executive sectors have to submit their annual and next year's programs, current incomes and

\footnotetext{
* Issa Daneshpour Bakhshayesh, Ph.D. of public law student, Tehran University, Pardis of Alborz. Research fields: Public Law, Constitution and Administrative Law Projects.

** Nina. H. A. Mohammady, Master of public law student, Tehran Central Branch, Azad University. Research fields: Public Law, Constitution and Administrative Law Projects.

Responsible writer: Issa Daneshpour Bakhshayesh.

${ }^{1}$. Article 13th of Program And Budget Organization Of Iran.
} 
constructive costs to the Program and Budget Organization of Iran.

Executive sectors mean all the organizations and ministries which are bound to enforce the budget programs, judiciary is one of them. Program and Budget Organization of Iran.

Judiciary power's role—as a budget user—divides into four categories:

\section{EVALUATION JUdiciary’s POWER IN BUdGETING PROCESS}

\section{A. Preparing and Proposing the Budget}

According to Principle 52 of Iranian Constitution, executive power is responsible for preparing the country's budget. It should be presented as a bill-not a legal draft by representatives of the parliament, Preparing the budget is an Ultra Vires action for executive power, any change or revise can be done on the text, however, judiciary power' s role in preparing is not more than a propose. ${ }^{2}$

\section{B. Enactment of the Budget}

Enactment of the budget is one of the specialized authorities of the parliament, which has been recognized in most of the legal systems, and is not against the separation of powers, but makes the applicability of rule of law in executive affairs and helps citizens to monitor the governments.

The Iran's government has a partial separation of powers, therefore parliamentary regimes system is enforcing, parliament's extensive authority to change bill of budget is a perfect instance.

As a member of cabinet, judiciary minister, is not authorized to defend the budget, therefore, in budget enactment process - the same as prepare and proposing-judiciary power is out of any legal devise to present its commercial requirements. ${ }^{3}$

\section{Budget Execution}

According to Principle 53 of Iranian constitution: All of the incomes and outcomes of the government would be according to related statutes to central treasury. Public offices send all their revenues to treasury and ask for

\footnotetext{
${ }^{2}$ Mohammad Emami, Enactment and Execution of the Budget in Public Audit Act, 5 Judiciary's LEGAL JOURNAL 1371 solar.

${ }^{3}$ Seyed Mohammad Hashemi, Comparative and Conceptual Evaluation of Iranian Constitution, 8 LEGAL RESEARCHES JOURNAL 1386 solar.
} 
their costs. ${ }^{4}$ This is due to centralization of costs and budgeting system's sovereignty. Although judiciary power is independent in administration, but in the budget is under authority of execution power and any regulation of commercial ministry should be enforced.

\section{Budget Observation}

Budget observation process in Iran divides into 3 categories:

Commercial observation, operational observation,

and Program observation.

Commercial observation is controlling incomes and outcomes of public office by accountants of economy and assets ministry in addition to hierarchy monitoring.

Operational observation is comparative evaluation of incomes and outcomes according to budget law. Budget and program organization and accounting bureau are responsible.

Program observation which pursuits an aim, and legislative power, applies it in two stages:

First stage: in ratification of the budget bill.

Second stage: after finishing the commercial year and reports of accounting bureau.

\section{NECESSITIES OF JUDICIARY BUdGET’S INDEPENDENCE}

\section{A. Separation of Power}

The nature of judiciary power's responsibilities needs a pure independence, in order to this nature, so-called power needs a separation from two other powers and budgeting regulations can be a way to achieve this aim. ${ }^{5}$ Executive power with preparing and legislative power with ratification and observation are important elements in budgeting system, however judiciary power does not play any role in such important process.

\section{B. Judicial Observation}

In Iranian legal system, judgment has an important role and judiciary is

\footnotetext{
${ }^{4}$ Mohammad Emami, General Commercial Law Texts 1384 solar (1st edition, Mizan Publication, Tehran).

${ }^{5}$ Issa Daneshpour Bakhshayesh, Evaluation of Judiciary Power's Independancy in Iranian Law, MASTER OF LAW THESIS 1378 solar (State University of Tabriz).
} 
the main power of observation and crime restriction in the society, so it needs to be separate and independent to any power.

\section{Judicial Independence}

Financial independence is one of the most important elements in judicial independence, and in some opinions it is the most important factor in supporting judiciary's independence. ${ }^{6}$ Unfortunately Iranian current constitution does not have any emphasis in this factor-in contrast to Iranian conditional (Mashrooteh) revolution's constitution in 1285 solar.

\section{Wide Sphere of Authorities}

According to Iranian constitution, judiciary power has a wide sphere of authorities, such as: observation, administration, political, social and cultural, whereas not having enough budget, it is impossible to apply all its authority.

\section{UNIFICATION OF BUDGET, IN CONTRAST WITH BUDGET INDEPENDENCE}

According to unification of budget principle, none of the public sectors can submit its annual budget to parliament. And parliament should evaluate and analyze the budget, and manage the whole amount of budget, in this case judiciary power cannot have any independent budget. $^{7}$

\section{PRoposals For Budget INDEPENDENCE}

Judiciary power is under the effect of other two powers (executive power and legislative power), which this effect is not in coordination with semi-separation of power, this is an intervention in authority, and this intervention for executive power in preparing and legislative power in ratification, the budget is due to Iranian constitution's construction. ${ }^{8}$

Using Principle 52 of Iranian constitution, ratification of a new exclusive statute in budget preparation case might be a good way, due to lack of such statue, we can see large amount of changes in budget bill. Organic rule in French law is an instance, which prohibits parliament to

\footnotetext{
${ }^{6}$ Eric Barent, An Introduction to Constitutional Law 1382 solar (1st edition, Translated by Abbas Kadkhodayi, Mizan Publication, Tehran).

${ }^{7}$ Ali Mohammad Eqtedary \& Manouchehr Tehrany \& Mehrdad EtTehad, The Budget 1347 Solar (1st edition, Accounting Supreme Institute Publication, Tehran).

${ }^{8}$ Mohammad Hossein Zarei, Parliament's Monitoring Role and Its Principles, 48 ParLIAMENT AND RESEARCH JOURNAL 1383 solar (12th year).
} 
change the budget bill 9 .

Judiciary minister's defense from judiciary's budget bill in the parliament might be effective.

\section{CONCLUSION}

So in conclusion, we can argue that both executive and legislative powers' effect on budgeting process is more than settled amount in partial separation of powers authority, and, as a matter of fact, these two powers intervention in judiciary power's budget is undeniable, which is in contrast with judiciary power's independence.

The reasonable solution might be enacting new statutes or limiting previous authorities of executive and legislative powers in preparing, proposing and enacting judiciary power's budget-without detaching this budget from annual budget and allocating more to judiciary power to defend its budget in parliament. By so-called solutions the judiciary power's commercial independency might be expected.

\footnotetext{
${ }^{9}$ Mohammad Qasemi, The President and Budgeting Challenge in Iran, 46 PARLIAMENT AND RESEARCH JOURNAL 1382 solar (11th year).
} 